focus on German Studies.

https://journals.uc.edu/index.php/fogs

Issue 28 (2021)

Book Review

The Films of Konrad Wolf: Archive of the Revolution

by Larson Powell, Camden House, 2020. 312 pp. $\$ 82$

Troels Thorborg Andersen

Freie Universität Berlin

How to Cite: Andersen, Troels Thorborg. "Book Review: The Films of Konrad Wolf. Archive of the Revolution". focus on German Studies 28, no. 28, 2021, pp. 197-202. DOI: 10.34314/FOGS2021.00013. 


\section{The Films of Konrad Wolf: Archive of the Revolution}

\section{by Larson Powell, Camden House, 2020. 312 pp. $\$ 82$}

Troels Thorborg Andersen

In his latest book, The Films of Konrad Wolf. Archive of the Revolution, Professor of Film Studies Larson Powell offers a thorough and inspiring viewing of Konrad Wolfs filmography. In the introduction, Powell situates his book in the field of research on the former German Democratic Republic, film and Konrad Wolf's legacy, and he presents the theoretical lens of his viewings. 13 essays follow, each essay is dedicated to one of Wolf's films (one essay is on three of Wolf's minor films). Powell's theoretical focus is on the concepts of 'archive' and 'genre', and this enables him to frame Konrad Wolf's work in a broader historical and political context. Thus, the book not only offers insight into one of the GDR's most important filmmakers, it also contributes to contemporary debates on the cultural losses and the remains of the socialist state.

Konrad Wolf (1923-1982) made a total of 16 films in a span of 28 years, and he is considered one of the most significant directors from DEFA (Deutsche Film AG), the state film production company in the GDR. Powell has decided to examine the legacy of Wolf in the GDR by confronting the film archive of DEFA. This archive was of great importance to the GDR, because of the country's attempt to shape a national identity according to the historical materialism proposed by Marxist-Leninism. Powell identifies two different concepts of the 'archive': With Foucault, he understands the archive as a "suprapersonal dispositive" (15). In this view, the archive is material proof of media transition, and evidence of technological development. With Derrida, Powell understands the archive in psychoanalytical terms as a conservation of trauma. Powell operates with this 
double concept of 'archive' throughout the book, and it allows him to contextualize the film analysis in two ways: On one hand, Powell is describing the personal biography of "Poor Konrad" (3), on the other, the history of the GDR. According to the first context, Wolf's work was fueled by the difficult relationship to his father, the important playwright Friedrich Wolf, and by his youth as a German Jew in Moscow. After graduating from film school in Moscow, Konrad Wolf settled in the newly founded GDR in the 1950s and this is where his career as filmmaker takes off. According to the second context, Wolf's work is tightly connected to the political ideology of the country that he chose to be his home. Throughout his life, Wolf was faithful to the GDR state. As opposed to many other intellectuals of the country, he even supported the expatriation of the singer Wolf Biermann in 1976. Thus, Wolf's films are not only subjective portraits but also archived memories of the hopes, visions and self-perception of the GDR.

Powell views Wolf's film with the aim of pointing out specific political and aesthetical interests in each film. For example, in Wolf's first DEFA film Einmal ist keinmal (1955), Powell hears echoing the philosophy of hope formulated by the philosopher Ernst Bloch. According to Powell, the film shows that the dream of home or homeland (Heimat) is directed towards the future, that home is something that is yet to be found or built, opposite to the conservative idea of Heimat as the fatherland. This idea resonated with the socialist ideals of the young nation. A similar subject is to be found in the melodrama Lissy (1957). In the essay on this film, Powell delves into the theoretical problem of founding a nation without nationalism. The GDR understood itself first and foremost as an antifascist state, in fact, antifascism was considered to be the substitute of nationalism. This is the reason why many DEFA films in general and Wolf's films in particular are considered to be within the antifascist genre.

According to Powell, the antifascist genre is distinguished by the "conversion 
narrative" (50), an appropriation of the Bildungsroman to the medium of film and the ideology of Marxist-Leninism. The main character undergoes a process, in which he or she is appropriating a socialist and antifascist consciousness. Powell understands the antifascist film as a subgenre of the Gegenwartsfilm (film of present), a canonical genre of DEFA film and a genre that is more about subject matter (appropriation of socialist consciousness) than of filmic self-reflection (61-62). Gegenwartsfilm was created with the political purpose of intervening in the public sphere at a specific moment in time. In this respect, a political history of the GDR can be read out of the findings in the DEFA archive. And in this respect too, Konrad Wolf is to be considered a highly political filmmaker. Albeit Konrad Wolfs film production was not mere propaganda. With his adaption of Christa Wolf's famous novel Der geteilte Himmel (novel 1963, film 1964), Wolf introduced new wave cinema to the East German audience, and throughout the book, Powell often refers to and indirectly compares Konrad Wolf to the West German film icon Rainer Werner Fassbinder. Also, Powell sees reflection of Jean Luc Godard and Italian neorealism in Wolf's later films. However, with the 11th Plenum of the Central Committee of Socialist Unity Party in 1965, the times of aesthetic experiments were over in the GDR. From this point on, Wolf's films seem to focus more and more on questions of subjectivity and individuality than on experimenting with filmic form. In Wolfs last film Solo Sonny (1980), Powell observes a greater generic complexity in comparison with the earlier Gegenwartsfilm. The film deals with womanhood and feminism under socialism, and Powell argues that this film and its public popularity show how art is beyond control, even in a totalitarian regime. Powell's argument of the archive's relevance to understand Konrad Wolf and DEFA's role in the GDR is comprehensive and well-structured along the line of the 13 essays. The reader can choose to read the book in its entirety to see the full development of Wolf's filmography, or the reader can decide to pick a single essay and get detailed insight into a 
specific film. The former approach seems particularly helpful. The book is very well documented with many references to studies relevant for everybody interested in GDR history. In fact, The Films of Konrad Wolf. Archive of the Revolution can be of interest for researchers not only within the field of Film Studies, researchers of Literary Studies and History may also find relevant insights. It is apparent - as the author states in the Acknowledgments - that the book is a result of 20 years of researching the topic.

Although the book is a product of thorough and persistent work, it does not come without some irritation. At times, readers may find the interpretations too densely contracted. Powell has the tendency of condensing his film interpretations into sometimes heavily digestible semantic chunks full of endnotes, which interrupts the flow of reading. This taken into consideration, the book might not be for everyone. But for anyone who is interested in contextualized close readings of Wolf's film, The Films of Konrad Wolf. Archive of the Revolution provides. Powell has accomplished his 20 -year mission writing this book, and academics interested in the filmic remnants of the GDR are here given a solid source of knowledge. 
focus on German Studies.

https://journals.uc.edu/index.php/fogs

\section{Works Cited}

Powell, Larson. The Films of Konrad Wolf: Archive of the Revolution. Campden House, 2020. 